\title{
The Belt and Road Initiative: A Legal Analysis-An Introduction
}

\author{
Giuseppe Martinico and Xueyan WU
}

The Belt and Road Initiative (BRI) is a multi-functional strategy launched by the People's Republic of China, which is based on a variety of instruments and measures.

The priorities of the BRI are different and ambitious, namely policy coordination, infrastructure connectivity, unimpeded trade, financial integration, people-to-people bond ${ }^{1}$ and development through six geographical corridors. As is evident, the realisation of this initiative will take ages and is part of a grand strategy, which may be read in different ways.

So far, the debate on the topic has mostly been dominated by scholars in international relations and geopolitics and economists (Xing 2019; Cheng et al. 2018; Mayer 2018). More recently, lawyers (Zhao 2018; Chaisse and Górski 2018; Shan et al. 2018) tried to enter into this

${ }^{\mathrm{l}}$ Full text of the Vision for Maritime Cooperation under the Belt and Road Initiative, https://www.fmprc.gov.cn/mfa_eng/zxxx_662805/t1249618.shtml.

\footnotetext{
G. Martinico $(\varangle)$

DIRPOLIS Institute (Institute of Law, Politics and Development), Sant'Anna School of Advanced Studies, Pisa, Pisa, Italy

e-mail: giuseppe.martinico@santannapisa.it

X. WU

School of Law, Chongqing University, Chongqing, China e-mail: wuxueyan@cqu.edu.in 
interdisciplinary debate. However, with the above-mentioned exceptions, the very few legal analyses that exist on this ambit are still superficial. Western scholars frequently refer to the initiative as mere propaganda while the Eastern contributions on the topic are above all descriptive (however, germs of a proper and critical legal approach can be found in recent articles [Wang 2019]). This volume aims to overcome this divide, taking into consideration the different Eastern and Western perspectives.

What does the BRI mean for the existing multilateral organisations? What can it represent for the future of the European Union in the long run? What is the role of hard and soft law in the functioning of the Initiative? What does it represent from a legal theory perspective?

This book gathers scholars from different backgrounds and several countries to provide a cross-country discussion.

In their chapter, Qingjiang Kong and Ming Du explore the BRI as an attempt at filling the vacuum characterising the global governance and a manifestation of the Chinese ambition to serve as a global leader. Lorenzo Zucca investigates the BRI in the light of two competing visions of global order, the Western one, fostered mainly by the United States, and the Chinese one emerging from the BRI.

Ernst-Ulrich Petersmann explores the issue of the international settlement trade and investment disputes concerning the BRI from the viewpoint of the European Union. Rule of law is one of the most ambiguous concepts in constitutional and political theory and we have decided to gather two very different perspectives on it. Yongmei Chen explores the concept of the rule of law fostered by the BRI. As we will see, the rule of law ideal is one of the major sources of misunderstanding between Western and Eastern scholars and this chapter offers important clarifications.

Henrik Andersen's contribution looks at the BRI from the viewpoint of the rule of law to identify some problematic gaps in terms of legal certainty for international businesses and other stakeholders.

Giuseppe Martinico explores the significant role acquired by soft law instruments in the scope of the BRI, by reconstructing its concept in international and comparative law. In his chapter, Imad Antoine Ibrahim analyses the role of international water law in the implementation of the Belt and Road Initiative, arguing that this area of international law constitutes an appropriate regulatory framework on the basis of which China can base the implementation of the Initiative.

The BRI represents an interesting test to verify how the Chinese ambition will impact on international law. Against this background, in her chapter, Xiaoling Tian investigates some burning issues on intellectual 
property cooperation in the context of the BRI. In her chapter, Xueyan WU introduces the main features of Chinese investments in the countries involved in the BRI by examining the current insurance system and its gaps. Indeed, China has not yet established a comprehensive legal framework covering the political risks of overseas investment. In addition, the legal protection provided by Bilateral Investment Treaties against political risk is insufficient. It is time to reconstruct China's overseas investment insurance system and speed up the signing and revision of BITs with countries in the OBOR region and around the world.

In the final part of the book, specific aspects of the BRI are investigated.

Wenge Zeng offers a diachronic analysis of some efforts made by the Chinese government at the end of the nineties, in particular, the 'Go Out' Policy, to stress its continuity and discontinuity with the BRI.

Shisong Jiang approaches the BRI to reflect upon the broader issue of the Chinese conception of the international legal system, dealing with the role of cities in international law.

Huichun Liu offers a comparative analysis of the reconciliation legislation and the judiciary system of countries along the BRI.

The book aspires to contribute to the international debate by gathering scholars from different backgrounds (legal theorists, public international lawyers, comparative lawyers) in a way that they can offer their inputs and observations concerning the BRI.

Special acknowledgements go to Imad Antoine Ibrahim who assisted us in the latest phase of the editorial project. We hope that this book might prove interesting, as it is likely to facilitate an exchange of ideas and a comparison between different practices to mutual benefit and understanding.

This book originates from an international conference organised in Pisa on 24 May 2019 within the frame of the Sant'Anna Legal Studies initiative. STALS (Sant'Anna Legal Studies) is a project made possible thanks to the financial support offered by Scuola Superiore Sant'Anna, issued within the framework of the School's internationalisation policy. The conference was organised after the signature of the Memorandum of Understanding between China and Italy and was kindly funded by the Confucius Institute of Pisa. While finalising this collection, the coronavirus crisis exploded and our Chinese colleagues in particular have suffered from many inconveniences, so this book is dedicated to those who believe in transnational friendship even in hard times. 


\section{REFERENCES}

Chaisse, Julien and Górski, Jędrzej (eds.) (2018), The Belt and Road Initiative Law, Economics, and Politics, Brill, Leiden.

Cheng, Yu, Song, Lilei and Huang Lihe (eds.) (2018), The Belt \& Road Initiative in the Global Arena: Chinese and European Perspectives, Palgrave, New York.

Mayer, Maximilian (ed.) (2018), Rethinking the Silk Road China's Belt and Road Initiative and Emerging Eurasian Relations, Palgrave, New York.

Shan, Wenhua, Nuotio, Kimmo and Zhang, Kangle (eds.) (2018), Normative Readings of the Belt and Road Initiative: Road to New Paradigms, Springer, Berlin.

Wang, Heng (2019), "China's Approach to the Belt and Road Initiative: Scope, Character and Sustainability", in Journal of International Economic Law, 22(1), 29-55.

Xing, Li (ed.) (2019), Mapping China's 'One Belt One Road' Initiative, Palgrave, New York.

Zhao, Yun (ed.) (2018), International Governance and the Rule of Law in China under the Belt and Road Initiative, Cambridge University Press, Cambridge. 